Jesuit Institutional Change in the 1970s: Its Impact on Jesuit Sources and Historiography, and the Future of Jesuit Archives in Francophone Africa and Europe

Authors: Barbara Baudry and Jean Luc Enyegue, S.J.

Source: Engaging Sources: The Tradition and Future of Collecting History in the Society of Jesus (Proceedings of the Symposium held at Boston College, June 11-13, 2019)

Edited by: Cristiano Casalini, Emanuele Colombo, and Seth Meehan

ISBN: 978-1-947617-09-4

Published by: Institute of Jesuit Sources

Originally Published: March 1, 2021

https://doi.org/10.51238/ISJS.2019.31

Provided in Open Access by the Institute for Advanced Jesuit Studies at Boston College.

The Institute of Jesuit Sources, specializes in preserving, maintaining, and expanding for scholars around the world important texts and studies in Jesuit history, spirituality, and pedagogy.

Visit our website at https://jesuitsources.bc.edu 


\title{
Jesuit Institutional Change in the 1970s: Its Impact on Jesuit Sources and Historiography, and the Future of Jesuit Archives in Francophone Africa and Europe
}

\author{
BARBARA BAUDRY AND JEAN LUC ENYEGUE, S.J.
}

This essay explores how institutional change within the Jesuit order and the Africanization of the Society during the twentieth century has affected the production, collection, and conservation of sources relating to its work in Africa. ${ }^{1}$ It also explores how these changes could affect the writing of the current period of Jesuit history in French-speaking Africa. The end of the French overseas missions stripped French Jesuit archives of one of their most important sources of information and changed the quality of the sources, making their content poorer on culturally related issues. With the merger of French Jesuit provinces, the nature of the sources became overwhelmingly governance- and ministries-oriented, yet this shift also had the positive effect of relocating the archives to a single place, making it easier for researchers on French Jesuit history to access them.

On the African side, the evolution from missionary to African Christianity also reinforced a qualitative change in the archives, while the multiplication of Jesuit jurisdictions in Africa led to the scattering of sources throughout the continent. Historians of Francophone Africa's Jesuit history are therefore confronted with a double challenge. On the one hand, how does he or she access the scattered sources of Jesuit history, especially since the delivery of the same to the central archive of Western Francophone Europe effectively ceased with the end of the missions? On the other hand, how does the quantitative and qualitative change of Jesuit sources from missionary to African Christianity affect the writing of Jesuit history in French Africa?

This essay explores new ways of reorganizing the Jesuit archives in France and Africa in order to enhance the production, collection, and preservation of sources and ensure that they are efficiently distributed and accessible to researchers. The first part gives an account of traditional ways of producing, collecting, conserving, and distributing Jesuit archives in French Africa and the nature of Jesuit historiography this old model might produce. In the second part, the essay analyzes the quantitative and qualitative changes in the production, collection, conservation, and distribution of Jesuit sources and how these changes could influence the writing

\footnotetext{
1 "Africanization" refers to the emergence of a church that is genuinely African, rooted in African culture, shaped by African values, and led by Africans.

https://doi.org/10.51238/ISJS.2019.31

(C) Institute of Jesuit Sources, 2021
} 
of Jesuit history in French-speaking Africa and the reorganization of Francophone Jesuit archives in Europe and Africa. This essay is a first attempt by the Jesuit archives in the province of Francophone Western Europe (EOF) ${ }^{2}$ and the Jesuit Historical Institute in Africa (JHIA) to address those challenges collaboratively.

\section{Archives and Historiography: The Missionary Era}

In 1961, Rev. Jean-Baptiste Janssens, superior general of the Jesuits (in office 1946-64), created the Jesuit province of Central Africa (ACE). In addition to what is today's Democratic Republic of Congo (DRC), ACE included the two other Belgian colonies in Central Africa, namely Burundi and Rwanda. ACE became the first Jesuit province in Africa, followed by the creation in Francophone Africa of Madagascar (1971) and West Africa (1973). Both the Congo and the Malagasy Jesuit missions had existed under Portuguese control from the early years of the Society. However, after the Society's restoration in 1814, France and Belgium took over the missions of Madagascar (1845) and the Congo (1893).

The organization of the Jesuit archives in French-speaking Africa often coincided with the beginning of the province. According to Jesuit Joseph de Cock, former archivist of the Central African province, the archives started like any other Jesuit archive, with "the orderly conservation of paper for each good purpose," but the task of organizing and preserving the material only started sixty years after the beginning of the mission, that is, when the mission had become a vice-province (and then province) and "had to demonstrate the titles of its properties" and "place its papers in order." 3 The archives include the pre-history of the province as well as diaries and deeds to houses and land. ${ }^{4}$ The organization of the archives later followed the model of the mother province (in this case, the Jesuit province of Belgium):

The first step was to place all the documents in a certain order, joined together and placed in boxes or bundles. As the boxes increased in number the need to carry out an inventory and to improve the organizational system became evident. A general organizational scheme that would allow additional documents to be added was found in the inventory of the archives of the Belgian provinces [...]. The organization in the computer has to be

\footnotetext{
${ }^{2}$ EOF: Europe Occidentale Francophone (Francophone Western Europe).

${ }^{3}$ Joseph de Cock, "The Archives of the Society of Jesus," in Scriptis tradere et fideliter conservare: Archives as "Places of Memory" within the Society of Jesus, ed. Thomas M. McCoog (Rome: Jesuit General Curia, 2003), 49-56, here 52-53.

${ }^{4}$ De Cock, "Archives of the Society of Jesus," 53.
} 
"thought" of or "conceived" by the archivist himself. The outcome is what counts. ${ }^{5}$

De Cock proposes ten categories of classification, each placed in chronological order to make it easy to locate them. The largest part of the archives contained materials related to Jesuit biographies, Jesuit governance, and apostolic works. As a result, publications on the history of the Society in Central Africa have often focused on its institutional evolution, from the early days of the Kwango and the Kwilu missions at the end of the nineteenth century to developments at the end of the twentieth century. ${ }^{6}$ Other publications have analyzed the socio-cultural impact of the mission, from creating an indigenous liturgy to reforming agriculture or building roads and bridges. ${ }^{7}$ Only a few publications have focused on ethnographic and biographic history. ${ }^{8}$

De Cock's classification is similar to the classification of the materials related to Madagascar in the archives of the former French Jesuit province of Toulouse. Gerald M. Berg shows that, in addition to Lettres des scolastiques, a newsletter of the Jesuit scholastics of the Toulouse province, there were at least eight additional categories with different contents, ${ }^{9}$ including a pre-history of the mission from missionary reports (FMa 110) and non-missionaries (FMa 111), several diaries written by missionaries (FMa 150 and 185), correspondence with vicars

${ }^{5}$ De Cock, "Archives of the Society of Jesus," 53.

${ }^{6}$ Léon de Saint Moulin, "La mission du Kwango de 1945 à nos jours, et le lent processus d'africanisation," in Les jésuites au Congo-Zaïre (Brussels: AESM, 1995), 166-78; Ivan de Pierpont, "La mission du Kwango," Missions Belges (November 1912): 401-8; Léopold Denis, Les jésuites Belges au Kwango, 1893-1943: Monographie sur la mission du Kwango, devenue actuellement les vicariats apostoliques du Kwango et de Kisantu (Brussels: L’Édition universelle, 1943); Fernand Mukoso Ng'ekieb, Les origines et les débuts de la mission du Kwango, 1879-1914 (Kinshasa: FCK, 1993); Anicet N'Teba Mbengui, La mission de la Compagnie de Jésus au Kwilu: Contribution à la transformation d'une région congolaise, 1901-1954 (Rome: Pontificia Università Gregoriana, 2010).

${ }^{7}$ René Butaye, "Mission du Kwango: Les mœurs indigènes," Missions Belges de la Compagnie de Jésus 2 (1900): 193-98; 264-67; de Saint Moulin, "La mission du Kwango"; editors, "Fondation de cinq nouveaux villages chrétiens au Kwango," Missions Belges (1901): 148-49; A. Renard, "Mission du Kwango: Au service des malades," in Missions Belges de la Compagnie de Jésus: Congo, Bengale, Ceylan (Brussels: Charles Bulens, 1908), 24-35; X., "L'évangélisation des adultes dans la mission du Kwango," Missions Belges (1912): 150-54; Jules van de Casteele, "Musique indigène, musique religieuse," Revue du Clergé Africain 3 (September 1948): 392-96.

${ }^{8}$ Eugène Laveille, L'évangile au centre de l'Afrique: Le P. Van Hencxthoven, S.J., fondateur de la mission du Kwango, Congo Belge, 1852-1906 (Louvain: Museum Lessianum, 1926); Pierre Tromont, Le Frère Frans de Sadeleer S.J.: Un missionnaire des temps hérö̈ques; Co-fondateur de la mission du Zambèze et de la mission du Kwango (Louvain: L'Aucan, 1932); editors, "Quelques notions sur les populations de notre vicariat du Kwango," Revue missionnaire des jésuites Belges 9 (April 1935): 180-83; editors, "Vicariat apostolique du Kwango: Statistiques, 1937-1938," Revue missionnaire des jésuites Belges 18 (January 1939): 26.

${ }^{9}$ Gerald M. Berg, "The Archives of the Jesuit Province of Toulouse Relating to Madagascar," History in Africa 5 (1978): 357-59. 
apostolic (FMa 180), and other classified and non-classified correspondence (FMa $190 ; 411 ; 435-40){ }^{10}$

According to Berg,

this journal [Lettres des scolastiques] consisted of letters written from missionaries in the field to their Apostolic Vicars. Such letters were then excerpted and summarized and sent on to Vals, a Jesuit training seminary, for circulation among the missionaries in training there. Originally the excerpts were hand-copied and arranged by region: Madagascar, India, Oceania, etc., but later they were lithographed or printed. ${ }^{11}$

The loss of the original letters makes the summaries of Lettres des scolastiques the best available material for examining the pre-history of the Jesuit province of Madagascar. ${ }^{12}$ This is especially true for the life of its earliest missionaries. ${ }^{13}$ Unlike other early missions, little ethnographic information is given in Lettres. Instead, much of the contents are administrative and biographical in nature. ${ }^{14}$ The administrative Lettres are marked as involving "European" and "Non-European" Jesuit superiors, hinting at the intercultural nature of the Malagasy Jesuit mission and its Indian (Goa) jurisdictional connection. ${ }^{15}$ Finally, the changing name of the Lettres is indicative of the changing history of the Society in France and Europe in the late nineteenth century in that it portrays the picture of the Society's forced exiles. Vals (Lettres de Vals), where the newsletter was first published in 1838, is in France; Uclés (Lettres d'Uclés), its title from 1882 to 1897, is in Spain; and Gemert (Lettres de Gemert), the name given from 1903 to 1914 , is in the Netherlands. ${ }^{16}$

\footnotetext{
${ }^{10}$ Berg, "Archives of the Jesuit Province of Toulouse."

${ }^{11}$ Berg, "Archives of the Jesuit Province of Toulouse."

12 The summaries have been published in Adrien Boudou, Les jésuites à Madagascar au XIXe siècle, vol. 1 (Paris: Beauchesne, 1940).

13 The first missionaries include Mar Finaz, Augustin Delbosc, Louis Jouen, Jean-Baptiste Cazet, Jean-Baptiste Labaste, Antoine Abinal, Alphone and Henri Taix, François Callet, and Pierre-Justin Caussèque.

${ }^{14}$ One biography drawing on this material, that of Jacques Berthieu, was published to advance his canonization process: Adrien Boudou, Le Père Jacques Berthieu (1838-1897) (Paris: Beauchesne, 1935); Victor Sartre, Jacques Berthieu, S.J.: Premier martyr de l'île Rouge (Toulouse: Prière et Vie, 1965); Vicarius Apost. Tananariven, "De aperitione processus etc. in causa Servi Dei P. Iacobi Berthieu," ARSI, June 1935.

${ }^{15}$ Cf. Stéphane Nicaise, Les missions jésuites dans l'Océan Indien: Madagascar, la Réunion, Maurice (Namur: Ed. Jésuites, 2015).

${ }^{16}$ Nicaise, Les missions jésuites dans l'Océan Indien. In the index of his short article, Berg writes: "For the writings of these missionaries see Bibliotheca Missionum (30 vols.: Freiburg/Rome, 191773), 17: 640-17; 17: 710-11; 17: 528-29; 18: 185-87; 18: 1018; 18: 119-21; 17: 783; 17: 817; 17: 725-27; 17: 788-89; and 18: 182-84, respectively" ("Archives of the Jesuit Province of Toulouse," 359).
} 
Lettres $d u$ Tchad was created by Victor Barjon in 1946. In its first edition, Charles Margot, superior of the Chad mission, indicates that the European benefactors of the mission were the newsletter's targeted audience: "We need prayers as does any work that is this large and difficult; we also need other things such as material goods. As we stand, we lack almost everything." 17 This first edition also provided information on the weather, food, vegetation, fauna, and transportation, as well as describing Barjon's long trip across the Sahara and his early efforts to learn the Chadian languages. One of the cities he describes is the large and cosmopolitan Nigerian city of Kano. On September 29, 1946, Barjon wrote:

Kano is a big town populated by blacks. I do not understand a word of what they say. One of them, however, mixes some Arabic words that I am able to distinguish. Thanks to an English officer, Catholic and air station attendant, he helps me not only to leave the airfield, but to drive with him to some $5 \mathrm{kms}$ away. I arrive at the Catholic mission. The two Irish fathers to whom I speak in Latin welcome me fraternally. I say my Mass with joy, served by a black ebony who wears a beautiful red cassock. After Thanksgiving and breakfast, the officer comes to pick me up and takes me back to the train station. ${ }^{18}$

The Lettres also provide information on the early jurisdictional divisions of the mission territory, anticipating, in most cases, early maps of the future dioceses of the church of Chad and Cameroon, including, for Chad, Fort-Lamy (N'djamena) and Fort-Archambault (Sarh), and Foumban for Cameroon.

Courrier du Tchad (1947) replaced Lettres $d u$ Tchad and became the official newsletter of the mission. Courrier targeted Jesuit benefactors, family members, and friends back home in France. It provides information on the life and early works of the missionaries as they built the church from scratch. ${ }^{19}$ In its second edition, Margot describes the planning and administrative organization of the mission. ${ }^{20}$ Not surprisingly, as in Madagascar and Congo, early historical publications

\footnotetext{
${ }^{17}$ Victor Barjon, “Mission au Tchad,” Lettres du Tchad 1 (1946): 1-8, here 1.

18 Barjon, Lettres du Tchad.

${ }^{19}$ Victor Barjon, "Première lettre du P. Barjon," Courrier du Tchad 1 (1947): 1-4, here 1.

${ }^{20}$ Charles Margot, "Mission du Tchad," Courrier du Tchad 2 (1947): 1-5.
} 
on Jesuit work in Chad focused on the administration of the mission, ${ }^{21}$ the foundation of the church in Chad, ${ }^{22}$ and the lives of individual Jesuits who were pioneers of the mission. ${ }^{23}$ Yet because of Chad's cultural diversity, the European missionaries also published several grammar books, dictionaries, ${ }^{24}$ catechisms, ${ }^{25}$ and traditional Chadian rites. ${ }^{26}$ With European Jesuits, publications focused on biographical and cultural history until the 1960s, when the first Cameroonian Jesuits, namely Meinrad-Pierre Hebga, Fabien Eboussi Boulaga, and Engelbert Mveng, developed scholarship of their own, especially in the fields of philosophy, theology, and national history. ${ }^{27}$

${ }^{21}$ Joseph Fortier, Les débuts de l'évangélisation au Moyen Chari, diocèse de Sarh (les pionniers), 1946-1966, vol. 1 (Sarh: n.p., 1991); Fortier, Les débuts de l'évangélisation au Moyen Chari, diocèse de Sarh (la relève), 1966-1978, vol. 2 (Sarh: n.p., 1991); Fortier, "Chad," in Diccionario histórico de la Compañía de Jesús: biográfico-temático, ed. Charles E. O’Neill and Joaquín María Domínguez (Madrid: UPComillas, 2001), 1:745-51; Fortier, Notes chronologiques pour servir à l'histoire de la mission S.J. du Tchad (N'djamena: Imprimerie du Tchad, 1958).

${ }^{22}$ Jacques Hallaire and Jacques Fedry, Naissance d'une église africaine: Lettres et chroniques $d u$ Pays Sarh (Paris: Karthala, 1998); Charles Vandame, "Projet d'érection d'une circonscription ecclésiastique à Mongo par division des diocèses de N'Djamena et de Sarh (Tchad)" (unpublished, n.d.); Vandame, Cinquante ans de la vie de l'Eglise Catholique au Tchad (Paris: L'Harmattan, 2012).

${ }^{23}$ Joseph Fortier, Frédéric de Bélinay: Pionnier des missions du Tchad, vols. 1-2 (Fort Lamy: Imprimerie du Tchad, 1958); Charles Vandame and Benjamin Bamani, La joie de servir (Paris: Sarment-jubilé, 2009).

${ }^{24}$ Julien de Pommerol, L'arabe Tchadien: Emergence d'une langue véhiculaire (Paris: Karthala, 1997); de Pommerol, Dictionnaire Arabe Tchadien-Français (Paris: Karthala, 1999); de Pommerol, Grammaire pratique de l'arabe Tchadien (Paris: Karthala, 1999); de Pommerol, Contes et chants du Tchad (Paris: Ecole Pratique des Hautes Etudes, 1978); Jacques Hallaire, Au confluent des traditions de la savane et de la forêt: Étude thématique des contes Sar (Moyen-Chari, Tchad) (N'djamena: CEFOD, 1987); Jacques Fedry and Pascal Djiraingue, Prières traditionnelles du Pays Sara (Sarh: CEL, 1977).

${ }^{25}$ The authors did not have access to an original copy of the early catechisms in Chad, but several references to them are made in different documents and letters. See Paul Dalmais, "La mission du Tchad et les chrétiens de Fort-Lamy," Mitte Me 11 (1966): 16-27; Dalmais, "Un monde qui naît: La mission du Tchad," Jésuites 3 (1959): 31-37.

${ }^{26}$ Joseph Fortier, Dragons et sorcières: Contes et moralités du Pays Mbaï (Paris: Armand Colin, 1974); Fortier, Contes Ngambaye (Fort Lamy: Mission Catholique, 1972); Fortier, Le mythe et les contes de Sou en Pays Mbaï-Moïssala (Paris: Julliard, 1967); Jacques Fedry and Pascal Djiranigue, Prières traditionnelles du Pays Sara (Sarh: CEL, 1977).

${ }^{27}$ Pierre Meinrad Hebga, Personnalité africaine et Catholicisme (Paris: Présence Africaine, 1963); Fabien Eboussi Boulaga, Bantou problématique (Paris: Présence Africaine, 1968); Engelbert Mveng, "Structures fondamentales de l'art négro-africain," Présence Africaine 1 (1964): 116-28, here 116; Mveng, "L'Afrique chrétienne au Premier Festival Mondial des Arts Nègres," Revue du clergé Africain 5 (September 1966): 397-99; Mveng, Si Quelqu'un [...] (Tours: Mame, 1962); Mveng, "L'art africain: II; Le rythme," Présence Africaine 52 (1964): 104-27; Engelbert Mveng and Dominique Beling-Nkoumba, Manuel d'histoire du Cameroun (Yaoundé: CEPER, 1969); Mveng, Histoire du Cameroun, 1st ed. (Paris: Présence Africaine, 1963). 


\section{The Emerging Africanization in Jesuit Writings}

The focus of the publications of the first Cameroonian Jesuits shifted after the creation of the Jesuit province of West Africa in 1973. With one exception, ${ }^{28}$ none of the publications focused on the history of the Jesuits as such. Yet the institutional evolution of the Jesuit jurisdiction in West Africa ultimately shaped the missiological shift of their publications, giving them a postcolonial and anti-missionary accent. A close analysis of this change, in a previous work, ${ }^{29}$ suggests a direct link between this intellectual shift and the institutional position of these first Cameroonian Jesuits within the Jesuit order and the church.

At the time of writing this piece in 2019, after the end of the European missions in Africa, the archival collections of the former French provinces of Paris, Lyon, Champagne, and Toulouse cover many areas and tend to follow the same sixfold classification: (1) governance and administration, (2) training, (3) houses, (4) missions, (5) personal files of Jesuits, and (6) activities and ministry. The following charts show the volume of documents for area of study or collection before and after the end of the missions. ${ }^{30}$

Chart 1. Volume of Archives Holdings Before 1976

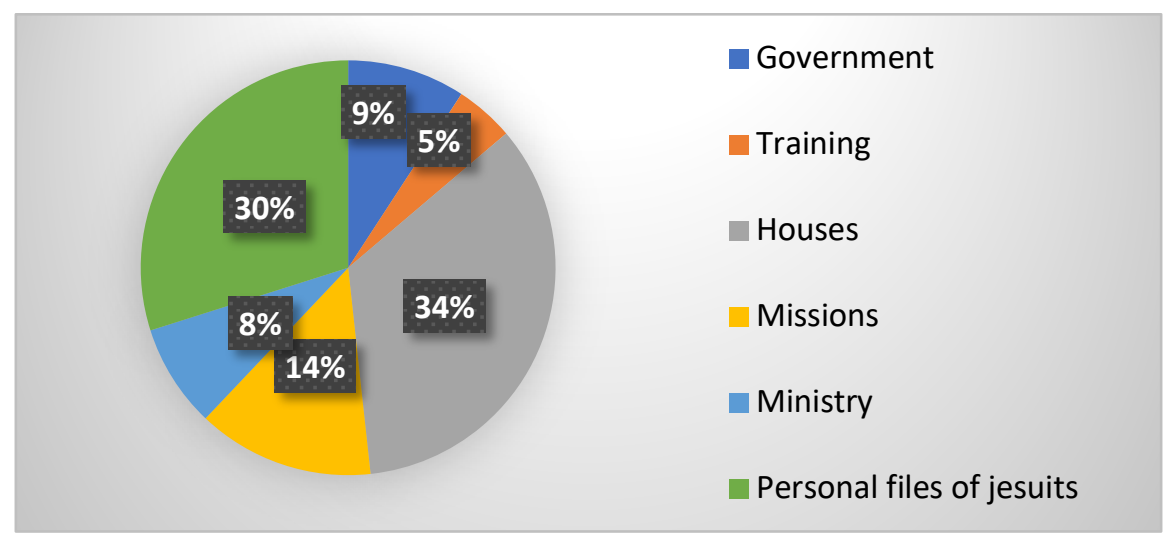

\footnotetext{
${ }^{28}$ The exception is Mveng's article "Camerún" in O'Neill and María Domínguez, Diccionario histórico de la Compañía de Jesús, 612-15. However, in the immediate aftermath of the creation of the Jesuit vice-province of West Africa, the nature of the postcolonial African church and the future of "missions" became his main focus.

${ }^{29}$ Jean Luc Enyegue, "The Creation of the Jesuit Province of West Africa and the Challenges of Africanization, 1946-1978" (PhD diss., Boston University, 2018); Enyegue, "Africanize Christianity or Christianize Africanity? The Cameroonian Reaction to Global Catholicism in the 1970s," paper presented at the conference "Global History and Roman Catholicism," University of Notre Dame, Indiana, April 4-6, 2019.

${ }^{30}$ Statistics from the archives of the EOF province.
} 
Chart 2. Volume of Archives Holding 1976-2017

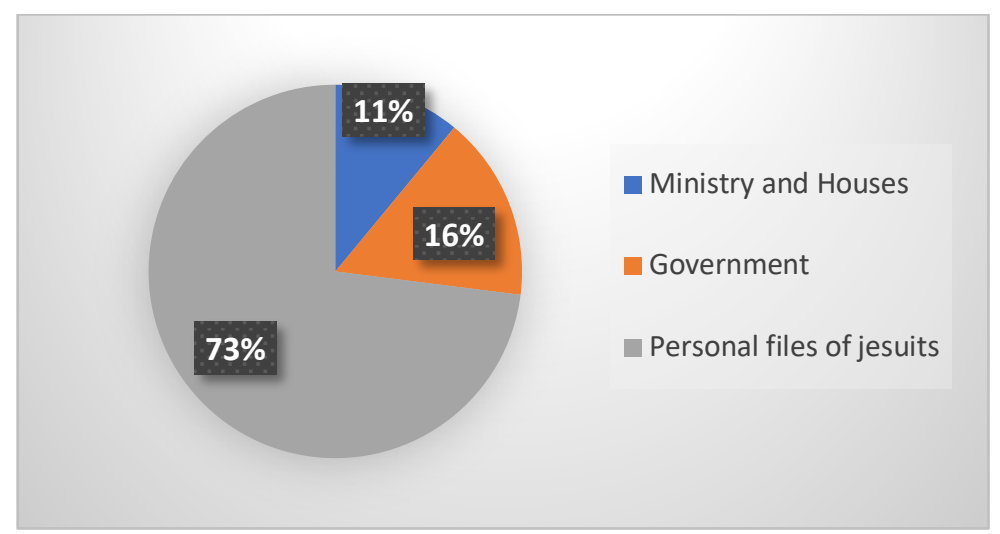

Chart 3. Research Topics

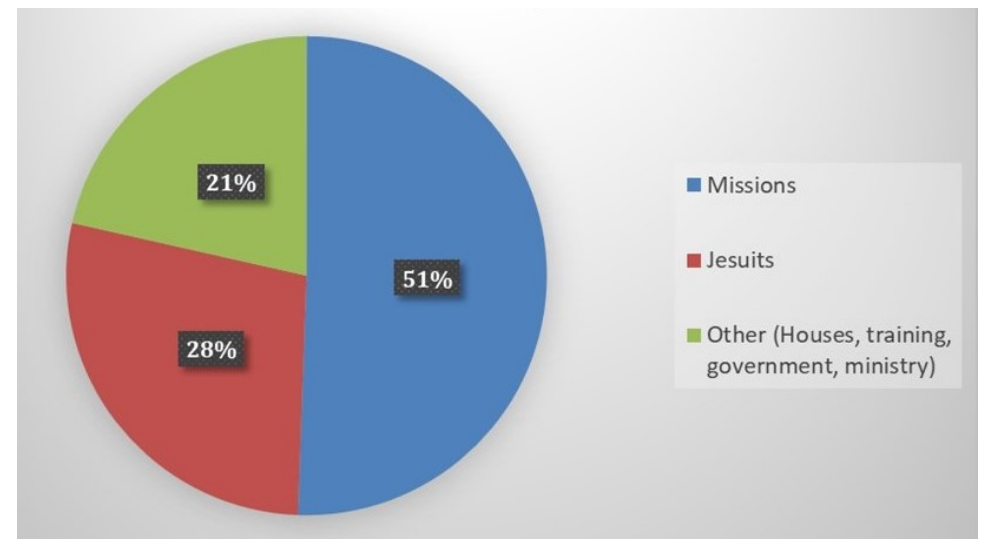

A thorough analysis of this data shows that, from $1976,{ }^{31}$ mission files have disappeared, while the personal files in the archives have more than doubled. Moreover, as the membership has decreased, files related to governance have almost doubled, while files on ministries have remained stable with a slower rate of decline from eleven to eight percent. The doubling of governance files might be related to an increased amount of bureaucracy due to the amalgamation of provinces. On the other hand, and related to the slower diminution of ministries, the governance of the Society in Francophone Europe might simply have expanded in order to maintain most of the traditional ministries despite the decrease in membership.

Mission materials remain the files most consulted by researchers. The charts also show that the content of the collections is less diverse and rich in terms of the

${ }^{31}$ In 1976, the four former provinces of France merged and became the united province of France. 
provenance of archives. Indeed, the end of the missions and the aftermath of the decade during and after the Second Vatican Council (1962-65) coincided with the closure of many Jesuit schools and an increase in secularization in France. ${ }^{32}$ Bruno Poucet has traced this secularizing trend in Jesuit schools to the Debré Law of December $31,1959 .{ }^{33}$ This process was confirmed and accelerated by the crisis of 1968. ${ }^{34}$ The continued decline of vocations from the 1970s in France also led to the decline in the direct supervision of schools by the Jesuits and other Catholic institutions $^{35}$ and less diversity in Jesuit archives, since the mission field had been a primary source for Jesuit archives.

Therefore, from 1976, archival holdings are essentially composed of: (1) personal files, (2) governance files, and (3) ministry files.

One can therefore make the hypothetical case that future historiographical research on the Society might focus mainly on Jesuit biographies, especially great intellectual Jesuits such as Henri de Lubac, Gaston Fessard, Pierre Teilhard de Chardin, and others; or Jesuit historiography might make a shift toward institutional and social history, drawn from governance and ministries files. Some of the social sources are not yet sufficiently exploited, including the writings related to ministry (Jesuit periodicals), social movements, works and missions (Table de Cana [Cana table], Mission Ouvrière [Workers' mission]), pastoral associations (Communauté de Vie Chrétienne [Christian life community], Mouvement Chrétien des Cadres [Movement of Christian leaders], Mouvement Eucharistique des Jeunes [Eucharistic youth movement] etc.), spiritual centers, youth chaplaincies, hospitals, prison ministry, and so on. The new frontiers of the mission such as Jesuit work among refugees, the socially marginalized, the poor, and the sick could potentially embrace the social and spiritual history of the Society as a new historiographical shift for this new millennium.

\footnotetext{
${ }^{32}$ Colin Roberts, "Secularisation and the (Re)formulation of French Catholic Identity," in Catholicism, Politics, and Society in Twentieth-Century France, ed. Kay Chadwick (Liverpool: Liverpool University Press, 2000): 260-79, here 268.

${ }^{33}$ Bruno Poucet, "Les collèges jésuites et la formation des élites: L'impact de la Loi Debré," Le télémaque 39 (2011): 84-85.

${ }^{34}$ Yves Chiron, L'église dans la tourmente de 1968 (Paris: Artège, 2018), 113-14; Philippe Chenaux, Paul VI: Le souverain éclairé (Paris: Cerf, 2015), 221-53.

${ }^{35}$ Nicholas Beattie, "Yeast in the Dough? Catholic Schooling in France, 1981-95," in Chadwick, Catholicism, Politics, and Society, 197-218, here 203-7.
} 


\section{JHIA-EOF Collaboration}

As technical and institutional collaboration between the JHIA and the EOF province archives is being considered, some actions will be taken with repercussions for archival management. First are the procedures and the communicability of the archives' holdings, including issues of church law and restrictions on access. According to Roland M. Baumann, access is "the authority/right of a researcher (outside of government creators/receivers) to obtain information from or to do research in archival materials in the custody of an archives." ${ }^{36}$ Decisions on access to Jesuit archives are determined by policies put in place by the archivist and ultimately by the province socius, the provincial (at the province level), or the superior general (for the ARSI). ${ }^{37}$ Standardizing those policies and other adaptations to new media, therefore, is a necessary step for inter-provincial collaboration. Furthermore, according to the "Pastoral Function of the Archives" published by the Pontifical Commission of the Cultural Heritage of the Church (February 2, 1997), ${ }^{38}$ this networking is necessary for new evangelization and the preservation of the religious identity and charisma of the religious institutions involved. ${ }^{39}$

Specifically, the EOF province archives and the JHIA will try to develop a common and proactive policy of production and collection. This endeavor has an impact on appraisal policies. Barbara Baudry, the EOF province archivist, proposes setting up a project to collect oral archives of former French and Belgian missionaries in Africa. These interviews could be posted on the respective websites of both institutions. Moreover, whether they are kept in Africa, Belgium, or France, archives require a reclassification to established standards. Thus, the sharing of research instruments would be an opportunity to classify or reclassify these archives' holdings according to established standards. ${ }^{40}$ Standardization of

\footnotetext{
${ }^{36}$ Roland M. Baumann, "The Administration of Access to Confidential Records in State Archives: Common Practices and the Need for a Model Law," American Archivist 49, no. 4 (Fall 1986): 34969, here 351-52.

${ }^{37}$ De Cock, "Archives of the Society of Jesus."

${ }^{38}$ Gard Robin, "The Pastoral Function of Church Archives," Journal of the Society of Archivists 19, no. 1 (April 1998): 53-62.

${ }^{39}$ Francesco Marchisano, "The Archival Patrimony of Religious Families as a Key to the Church's Pastoral Mission of Inculturation into the New Millennium," in McCoog, Criptis tradere et fideliter conservare, 1-8; David Bracken, "The Pastoral Function of Church Archives: A Reflection on the Theological, Juridical, and Pastoral Context of Roman Catholic Diocesan Archives," Irish Theological Quarterly 82, no. 1 (February 2017): 60-71.

${ }^{40}$ In particular, she refers to international archival standards ISAD-G, ISAAR, EAD etc. Sarah Higgins and Gavin Inglis, "Implementing EAD: The Experience of the NAHSTE Project," Journal of the Society of Archivists 24, no. 2 (October 2003): 199-214; Jennifer Bunn, "Developing Descriptive Standards: A Renewed Call to Action," Archives and Records 1 (September 2013): 1-13;
} 
procedures and appraisal would be a necessary first step before digitizing any documents. In the same way, tools and storage-sharing on computing platforms can be set up: inventories, digitized documents, work tools such as management tables, and lists of transferring archives. The pooling of research instruments will allow better orientation for researchers and more advanced work.

Digital mediation is another big issue. One of the first steps that could be taken is the collection, classification, and digitization of the photographic collection. ${ }^{41}$ This would be done both by the EOF archives center and the JHIA. In the same way, all of the periodicals concerning Jesuits in Africa could be digitized and made accessible on the internet. Virtual exhibitions could also be possible on both websites that would help promote the archives' holdings. Despite the ongoing dispersion of the archives following the creation of new Jesuit jurisdictions in Africa, the information would remain centralized and easily accessible. This would allow each archive to remain the owner of its heritage while facilitating communication and sharing with others. ${ }^{42}$

To make all of these projects possible, we will have to build, supply, and maintain the network and make it grow. We have already started to plan a training program on archiving that is specific to the Society of Jesus and adapted to the specific archives' holdings of French-speaking Africa. Other more historic training may also be offered with internships of French staff in Africa and vice versa. Everyone involved must have a minimum amount of knowledge of the holdings and the operation of the other institution to be able to work in the same spirit of collaborative exchange.

Development and awareness work could also be done at the level of the Society. The implementation of educational actions, especially in Africa, would be an excellent tool for raising young people's awareness of their history and the history of the Society in their country and region, as well as the unique sources that the archives hold. Jesuit high schools are a place where such a project could start. All this work is aimed at reaching the broader public through the organization of

Elizabeth Shepherd and Rachel Pringle, "Mapping Descriptive Standards across Domains: A Comparison of ISAD (G) and SPECTRUM," Journal of the Society of Archivists 23, no. 1 (April 2002): 17-34.

${ }^{41}$ Photos taken by the French missionaries.

${ }^{42}$ A serious challenge to the digitization is its cultural mediation. While Baudry insists on the integral heritage of each archive, the issue of heritage goes beyond the context of a particular archive to include the cultural heritage of past memories, which can sometimes be conflictual, especially when they are memories of cultural encounters. See Erik Granly Jensen, "Access and History: The Digitisation of the Danish Broadcasting Archives and Its Cultural Heritage," International Journal of Media and Cultural Politics 8, nos. 2-3 (2012): 305-16, here 306; Michel Foucault, The Archaeology of Knowledge and the Discourse on Language (New York: Vintage Books, 2010), 191. 
seminars, workshops, and publications. The ultimate goal is to advance research and identify contributors to help us in mission. ${ }^{43}$

The review and analysis of past and present practices in collecting, preserving, and using Jesuit archives for Francophone Africa is a first step toward a new form of collaboration. We should, however, remain vigilant about the context that surrounds us, its shifts and evolution. According to Terry Cook, there has been a major shift in the tasks of the archivists themselves ${ }^{44}$ and how their own cultural biases affect the building of an archive..$^{45}$ Therefore, long-term cooperation between the EOF province archives and JHIA will require constant adaptation.

This project is an initial step toward a global approach of managing the African archives of the Society of Jesus. The creation of the JHIA in 2011 is already a first impetus toward this adaptation to Africa's history and the history of its sources. This project fits more broadly into the desire of the Society of Jesus to manage its archival heritage, to promote it and make it more accessible for researchers.

\footnotetext{
${ }^{43}$ Baudry is raising an important point that connects her thought with the pioneering work of T. R. [Theodore Roosevelt] Schellenberg (1903-70), who first understood the importance of school libraries for the professionalization of archival work. William W. Hardesty, "AA Proper Function of Library Schools': T. R. Schellenberg's Archives Institute at the University of Texas, 1960," Libraries \& Cultural Record 42, no. 2 (2007): 129-50, here 129, 142.

${ }^{44}$ Terry Cook, "Archival Science and Postmodernism: New Formulations for Old Concepts," Archival Science 1 (2001): 3-24; Cook, "Evidence, Memory, Identity, and Community: Four Shifting Archival Paradigms," Arch Sci 13 (2013): 95-120.

${ }^{45}$ Terry Cook, "Building an Archives: Appraisal Theory for Architectural Records," American Archivist 59 (Spring 1996): 136-43; Cook, "Macroappraisal in Theory and Practice: Origins, Characteristics, and Implementation in Canada, 1950-2000," Archival Science 5 (2005): 101-61.
} 